Мальчик М. В. ${ }^{[1 ; ~ O R C I D ~ I D: ~ 0000-0002-0917-191 X], ~}$ д.е.н., професор, завідувач кафедри маркетингу,

Адасюк I. П. [1; ORCID ID: 0000-0003-2575-2359], к.е.н., старший викладач кафедри маркетингу

${ }^{1}$ Національний університет водного господарства та природокористування, м. Рівне

\title{
ТАРГЕТИНГОВА РЕКЛАМА ЯК ІНСТРУМЕНТ ПРОСУВАННЯ БІЗНЕС-СТОРІНОК У СОЦІАЛЬНИХ МЕРЕЖАХ
}

У статті досліджено популярні сайти, соціальні мережі та види медійної інтернет-реклами. Розкрито зміст таргетингу як найбільш дієвого рекламного інструменту у соціальних мережах. Удосконалено таргетингові етапи та завдання у мережах «Фейсбук» та «Інстаграм». Розглянуто показники аналізу результативності таргетингової реклами 3 розкриттям економічної сутності кожного. Також впорядковано переваги та недоліки таргетингу за основними параметрами його налаштування.

Ключові слова: таргетингова реклама; реклама; інтернет-реклама; соціальна мережа; рекламні інструменти; вебсайт.

Вступ. Інтернет-мережа охопила 60\% населення світу, а прогнозні розрахунки Global Digital передбачають зростання користувачів соціальних мереж більше ніж на 50\%. 71\% українців регулярно використовує інтернет-мережу, у тому числі $50 \% €$ користувачами соціальних мереж. Вплив інтернету на повсякденне життя стрімко зростає, а крилатий вислів Стіва Джобса: «Якщо вас немає в мережі, ви не існуєте» стосується як звичайних фізичних осіб, так і бізнесу, адже жодна ефективна маркетингова стратегія розвитку та просування не обходиться без нього.

Така тенденція створює сприятливі умови використання все більшої кількості рекламних інструментів для побудови маркетингових комунікацій бізнесу з покупцями. Таргетингова реклама - найбільш розповсюджений інструмент, алгоритм якого постійно змінюється, потребує систематичного контролю та аналітики.

Теоретико-практичні аспекти інтернет-реклами досліджували у своїх працях багато науковців, зокрема Т. В. Куклінова [5], М. В. Мальчик [6], О. В. Мартинюк [7], І. М. Шиндировський [10]. Таргетингову рекламу як різновид вивчали О.С. Євсейцева [3], С. Б. Романишин [8] та інші. їі проблеми недостатньо розкриті на науковому рівні, адже маркетинг у соціальних мережах активно адаптується під швидку зміну вимог користувачів, відповідно існує потреба у подальших дослідженнях 
таргетингової реклами.

Метою статті $\epsilon$ дослідження та розробка теоретико-практичних рекомендацій з удосконалення етапів та завдань таргетингової реклами, визначення показників їі результативності, а також переваг та недоліків як інструменту просування бізнес-сторінок у соціальних мережах. Для досягнення поставленої мети виділено наступні завдання: провести аналіз популярних доменів та соціальних мереж в Україні; визначити стан ринку електронної комерції; структурувати сегменти медійної інтернет-реклами та виділити найбільш дієві у соціальних мережах; удосконалити етапи та завдання таргетингової реклами у Facebook та Instagram; розглянути основні показники аналізу результативності таргетингової реклами; впорядкувати ії переваги та недоліки за параметрами налаштування.

Основна частина. Соціалізація інтернету $є$ ключовим трендом сучасності. Соціальні мережі входять до 10 найбільш популярних доменів декілька років поспіль, займаючи 3 (Facebook) та 10 місця (Instagram) на рівні з пошуковими, банківськими, торгівельними та інформаційними сайтами (рис. 1).

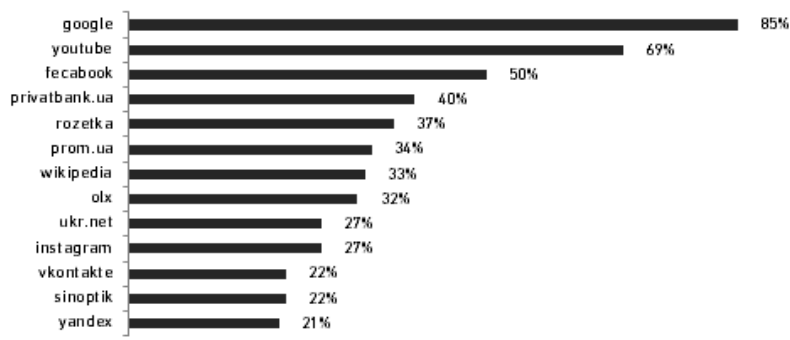

Рис. 1. Популярні домени у 2019 р. Джерело: [4]

Кількість користувачів соцмереж зросла на 9\% у світі, в Україні на 8\% у 2020 р. порівняно з 2019 р. Понад 50\% населення України використовує соціальні мережі. Найбільш популярною у рейтингу залишається мережа Facebook (рис. 2), кількість користувачів у 2019 р. склала $53 \%$.

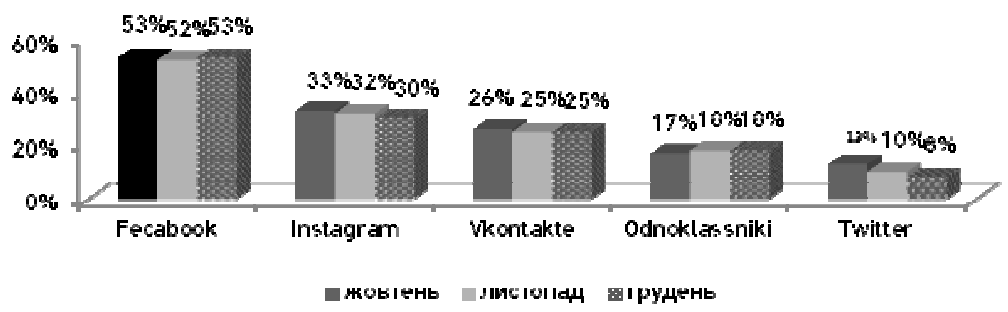

Рис. 2. Динаміка відвідуваності соціальних мереж за жовтень-грудень 2019 р. Джерело: [4] 
Друге місце у минулому році посіла соціальна мережа «Instagram» та витіснила з цієї позиції мережу «Vkontakte», інтерес до якої у 2019 р. зменшився на 5\% порівняно з 2018 р.

Серед усіх суспільних інституцій українці найчастіше використовують соціальні мережі для отримання інформації (68\%) [2], а $51 \%$ їм довіряють [9]. Такий інтерес суттєво впливає на динаміку зростання онлайн-купівель в Україні $-40 \%$ у 2019 р., коли у 2012 р. показник становив 17\% [11]. Відповідно до звіту Фонду електронної комерції, 72\% європейців здійснюють покупки в інтернеті, у США - 82\%, у Китаї - 61\% [12]. При цьому понад 41\% покупок провадиться через мобільні пристрої (табл. 1). Світова інтернет-торгівля очікує, що глобальні продажі електронної комерції В2С становитимуть понад 2 трлн дол. у наступному році [12].

Таблиця 1

Показники електронної комерції у 2019 році

\begin{tabular}{|c|c|c|}
\hline Країна / Частина світу & $\begin{array}{c}\text { Обсяг } \\
\text { онлайн-купівель, \% }\end{array}$ & $\begin{array}{c}\text { Частка використання } \\
\text { мобільних пристроїв при } \\
\text { онлайн-купівлі, \% }\end{array}$ \\
\hline Україна & 40 & 41 \\
\hline Європа & 72 & 50 \\
\hline Китай & 61 & 65 \\
\hline США & 82 & 45 \\
\hline
\end{tabular}

Джерело: $[1 ; 11 ; 12]$

Згідно статистики Marketing Sherpa 95\% людей у віці від 18 до 40 років вважають, що слідкувати за брендом та взаємодіяти 3 ним найзручніше саме через соціальні мережі. Бізнес давно помітив перспективу соціальних мереж у сприянні розвитку підприємницької діяльності, створюючи комерційні сторінки для інформування споживачів про товари / послуги, просування бренду та навіть прямих продажів. Такі сторінки є невід'ємною частиною побудови ефективної комунікації з цільовою аудиторією через найбільш найпопулярніші соціальні мережі - Facebook, Instagram. Без участі соціальних мереж сьогодні не обходиться жодна маркетингова стратегія, у якій рекламі відводиться значна увага.

Реклама в інтернеті (зокрема у соціальних мережах) - це динамічний та складний процес, проте доступний у режимі реального часу та зручний у редагуванні. Лідером медійної інтернетреклами у 2019 р. $\epsilon$ in-stream відео (рекламні ролики на початку, в середині, наприкінці відеоролика в уoutube.com) - 40\%, а також банерна реклама на другому місці - 35\% (рис. 3). 


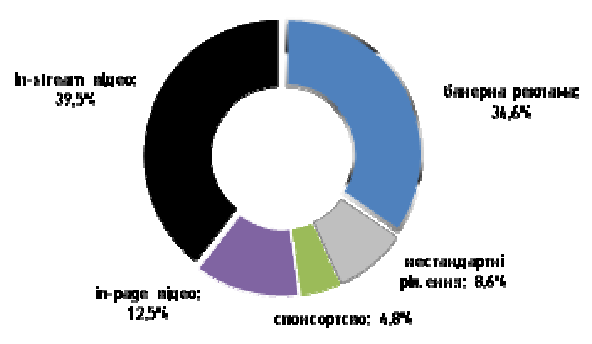

Рис. 3. Сегменти медійної інтернет-реклами у 2019 р. Джерело: [13]

Частка витрат на медійну рекламу у соціальних мережах займає 46\% від загальної величини витрат медійної інтернет-реклами, що на $11 \%$ більше ніж у 2018 р. [13]. Найпоширенішим видом медійної інтернет-реклами у мережах «Facebook» та «Instagram» залишається банерна реклама. Вона може мати вигляд графічного зображення, містити елементи анімації чи навіть бути анімованим відеофільмом, що надасть вичерпну інформацію про продукт.

Прогнозуючи нові тренди медійної реклами у Facebook та Instagram, варто враховувати зручність перегляду на мобільному пристрої, а також пам'ятати про аналіз цільової аудиторії, на яку спрямована реклама. 3 цією метою соціальні мережі використовують таргетингову рекламу як інструмент просування, зорієнтований на задану категорію користувачів, незалежно від того, здійснюють вони пошук даного товару / послуги у цей момент чи ні. Параметри таргетингу допомагають чітко обрати потенційного покупця.

Управління та налаштування таргетингової реклами передбачено у рекламному кабінеті «Ads Manager» соціальної мережі «Facebook». B Instagram також доступна частина рекламних налаштувань, які потребують удосконалення. Таргетинг у Facebook та Instagram розпочинається із аналізу ринку збуту, конкурентів, цільової аудиторії. Чим детальніше класифікувати аудиторію, тим кращою буде результативність реклами. Етапи таргетингової реклами у соціальних мережах можна поділити на три групи: підготовчий, безпосередньо таргетинг, заключний. У таблиці 2 наведено завдання до кожного етапу.

у рамках мети таргетингової реклами можна налаштувати параметри для стимулювання показу самої рекламної публікації, заходів чи збільшення кількості підписників бізнес-сторінки. Додатково доступна «кнопка із закликом до дії», що стимулює аудиторію до рішучості придбання товару чи послуги. Аудиторію можна класифікувати за різними критеріями: поведінковими, тимчасовими, соціально-демографічними. 3 одного боку, це звужує коло потенційних покупців, з іншого - підвищує результативність кожного показу реклами, адже врахований індивідуальний підхід та інтереси потенційного клієнта. 
Етапи та завдання таргетингової реклами у Facebook та Instagram

\begin{tabular}{|c|c|c|}
\hline $\begin{array}{c}\text { № } \\
3 / \Pi\end{array}$ & Етапи & Завдання \\
\hline \multirow{6}{*}{1.} & \multirow{6}{*}{ Підготовчий } & - аналіз ринку збуту, конкурентів, цільової аудиторії \\
\hline & & $\begin{array}{l}\text { - створення особистого профілю у Facebook чи використання } \\
\text { існуючого, наповнення його контентом }\end{array}$ \\
\hline & & $\begin{array}{l}\text { - створення бізнес-сторінок у Facebook та Instagram } \\
\text { (прив'язка акаунтів між собою, визначення ролей на бізнес- } \\
\text { сторінці у Facebook) }\end{array}$ \\
\hline & & $\begin{array}{l}\text { - створення та налаштування параметрів бізнес-менеджера } \\
\text { (якщо провадиться керування декількома бізнес-сторінками } \\
\text { та рекламними кабінетами) }\end{array}$ \\
\hline & & $\begin{array}{l}\text { - створення рекламного кабінету - Ads Manager (з одного } \\
\text { профілю можна створити один рекламний кабінет) }\end{array}$ \\
\hline & & - наповнення бізнес-сторінок контентом \\
\hline \multirow{4}{*}{2.} & \multirow{4}{*}{ Таргетинг } & - створення нової рекламної кампанії у Ads Manager \\
\hline & & - обрання мети (впізнаваність, лід, конверсія) \\
\hline & & $\begin{array}{l}\text { - налаштування рекламних параметрів (назва набору } \\
\text { реклами, вибір рекламної сторінки, бюджет, тривалість, } \\
\text { цільова аудиторія, плейсменти - місце показу реклами, } \\
\text { пристрої показу, інші додаткові параметри) }\end{array}$ \\
\hline & & - безпосереднє створення рекламної публікації \\
\hline \multirow{2}{*}{3.} & \multirow{2}{*}{ Заключний } & - перегляд та контроль статистики рекламної публікації \\
\hline & & - аналіз результативності реклами \\
\hline
\end{tabular}

На заключному етапі досить важливо контролювати використання рекламного бюджету та вчасно проводити аналіз результативності. Це можна робити як у процесі показу реклами, так і по іiі завершенню. Показників аналізу таргетингової реклами досить багато. У табл. 3 наведено найбільш поширені 3 точки зору практики, що використовують сучасні SMM-агентства. Наведені показники доступні у режимі налаштування параметрів рекламного звіту та автоматизовані у рекламному кабінеті.

Таблиця 3

Показники аналізу результативності таргетингової реклами

\begin{tabular}{|c|l|l|}
\hline Показники & \multicolumn{4}{|c|}{ Економічна сутність } \\
\hline 1 & \multicolumn{4}{|c|}{} \\
\hline Покази & Кількість рекламних показів \\
\hline Частота & Скільки разів у середньому кожна людина побачила рекламу \\
\hline Бюджет & Сума рекламних витрат \\
\hline Лід & $\begin{array}{l}\text { Кількість людей, які перейшли за посиланням на цільову } \\
\text { сторінку та здійснили реєстрацію у результаті проведеної } \\
\text { реклами }\end{array}$ \\
\hline Ціна за лід & Розмір рекламних витрат на кількість лідів \\
\hline $\begin{array}{c}\text { СтR } \\
\text { переходи за } \\
\text { посиланням) }\end{array}$ & $\begin{array}{l}\text { Підсоток людей, що побачили рекламу та перейшли за } \\
\text { посиланням на цільову сторінку: } \\
\text { Кількістперодів }\end{array}$ \\
\hline
\end{tabular}




\begin{tabular}{|c|c|}
\hline $\begin{array}{c}\text { Індекс } \\
\text { конверсії }\end{array}$ & Скільки продажів припало на один показ: \\
\hline
\end{tabular}

Таргетингова реклама у соціальних мережах актуальна для усіх видів діяльності, форм власності та розмірів бізнесу. Вона характеризується значною кількість переваг для сфери підприємницької діяльності, проте містить і недоліки, які наведено у таблиці 4, за основними параметрами налаштування таргетингу.

Таблиця 4

Переваги та недоліки таргетингової реклами у Facebook та Instagram

\begin{tabular}{|c|c|}
\hline Переваги & Недоліки \\
\hline 1 & 2 \\
\hline \multicolumn{2}{|c|}{ Управління } \\
\hline $\begin{array}{l}\text { Зручність управління двома соціальними } \\
\text { мережами з одного рекламного кабінету } \\
\text { Facebook }\end{array}$ & \multirow{2}{*}{$\begin{array}{llr}\text { Параметри } & \text { реклами } & \text { варто } \\
\text { налаштовувати окремо для } & \text { різних } \\
\text { соціальнихмереж } & & \end{array}$} \\
\hline $\begin{array}{l}\text { Можливість використання без наявності } \\
\text { вебсайту }\end{array}$ & \\
\hline \multicolumn{2}{|c|}{ Аудиторія } \\
\hline \multirow{2}{*}{$\begin{array}{l}\text { Можливість вибору цільової аудиторії за } \\
\text { конкретним параметрами }\end{array}$} & $\begin{array}{llr}\text { Перед } & \text { налаштуванням } & \text { таргетингу } \\
\text { потрібно } & \text { вивчити потреби цільової } \\
\text { аудиторії } & & \end{array}$ \\
\hline & $\begin{array}{l}\text { Рекламні макети та налаштування варто } \\
\text { орієнтувати на кожну групу цільової } \\
\text { аудиторії окремо }\end{array}$ \\
\hline \multirow{2}{*}{ Велике охоплення аудиторії } & $\begin{array}{l}\text { Систематична зміна вимог аудиторії до } \\
\text { рекламних оголошень }\end{array}$ \\
\hline & $\begin{array}{l}\text { Низький рівень конверсії рекламодавця } \\
\text { з цільовою аудиторією }\end{array}$ \\
\hline \multicolumn{2}{|c|}{ Бюджет } \\
\hline \multirow[t]{2}{*}{$\begin{array}{l}\text { Можливість обрати мінімальний } \\
\text { рекламний бюджет }\end{array}$} & $\begin{array}{l}\text { Розширення } \quad \text { рекламної } \\
\text { (охоплення) } \quad \text { подиторії } \\
\text { розміру рекламного бюджету }\end{array}$ \\
\hline & Потребує довгострокових інвестицій \\
\hline на цінова політика & \multirow{2}{*}{$\begin{array}{lr}\text { Ризик нераціонального } & \text { використання } \\
\text { бюджету через } & \text { неправильні } \\
\text { налаштування реклами } & \\
\end{array}$} \\
\hline Широкий діапазон цін & \\
\hline \multicolumn{2}{|c|}{ Детальний таргетинг } \\
\hline $\begin{array}{l}\text { Можливість редагування рекламних } \\
\text { параметрів під час показу (збільшення } \\
\text { бюджету, охоплення, інтереси аудиторії, } \\
\text { час показу) }\end{array}$ & $\begin{array}{l}\text { Існує ймовірність похибки у показах } \\
\text { реклами через відсутність досвіду у } \\
\text { налаштуванні параметрів }\end{array}$ \\
\hline \multicolumn{2}{|c|}{ Аналіз результативності } \\
\hline \multirow[b]{2}{*}{$\begin{array}{l}\text { Аналіз результативності реклами у } \\
\text { процесі показу та по завершенню }\end{array}$} & Мінімальна тривалість результативності \\
\hline & $\begin{array}{l}\text { Результативність продажів часто } \\
\text { зростає після показу декількох } \\
\text { рекламних звернень }\end{array}$ \\
\hline
\end{tabular}


Висновки. Популярність соціальних мереж серед усіх доменів очевидна. We Are Social та Hootsuite прогнозують, що до середини наступного 2021 р. більше половини населення використовуватиме соціальні мережі, хоча мотивація до конверсії користувачів соціальних мереж трохи нижча ніж у відвідувачів пошукових систем. У них немає більш вираженої потреби у товарі або послузі ніж у тих, хто цілеспрямовано шукає товар в інтернеті. Потрібно враховувати, що соціальна мережа - місце для розваг, відпочинку.

Таргетингова реклама як інструмент просування бізнес-сторінок у соціальних мережах дозволяє вирішити дану проблему шляхом раціонального використання рекламних інструментів, підвищує інтерес цільової аудиторії до товару / послуги у активний рекламний період та довгостроковий майбутній. Налаштування таргетингу зручні у редагуванні параметрів цільової аудиторії, яку може зацікавити пропозиція, тому показ рекламної публікації буде чітко визначений. На кожному етапі таргетингової реклами варто вчасно переглядати та контролювати статистику, аналізувати результативність. Незважаючи на всі переваги та недоліки таргетингу як інструменту просування бізнес-сторінок у соціальних мережах, він залишається найперспективніший на ринку інтернет-реклами, а соціальні мережі майданчиком пошуку та купівлі необхідного продукту.

1.Глобальна електронна комерція: + 2 трлн доларів доходу в 2019 році. URL: https://blog.lengow.com/global-ecommerce-2019-report/ (дата звернення: 16.09.2020). 2. Довіра українців до ЗMI за рік знизилася на $11 \%$. Укрінформ. URL: https://webcache.googleusercontent.com/search?q=cache:

46vqMJF3MBYJ:https://www.ukrinform.ua/rubricsociety/2803560-dovira-ukrainciv dozmiza-rik-znizilasanahtml+\&cd=1\&hl=uk\&ct=clnk\&gl =ua. (дата звернення: 16.09.2020). 3. Євсейцева О. С., Меркулова Д. Д. Таргетинг - цілеспрямований вплив на споживача. Економіка та держава. 2019. № 3. С. 107-113. 4. Звіт «Цифрові технології 2020» (Digital 2020). URL: https://wearesocial.com/blog/2020/01/digital-2020-3-8-billion-people-usesocial-media\# (дата звернення: 16.09.2020). 5. Куклінова Т.В. Інтернет-торгівля як засіб підвищення конкурентоспроможності підприємств в умовах глобалізації. Теоретичні, методологічні та практичні аспекти конкурентоспроможності підприємств : монографія / за заг. ред. О.Г. Янкового. Одеса : Атлант, 2017. С. 183-191. 6. Мальчик М. В., Клімавічус Я. І., Мальчик Я. Я. Маркетингові інтернет-технології в бізнесі. Маркетингові інновації в освіті, туризмі, готельно-ресторанній, харчовій індустрії та торгівлі : Міжнародна науково-практ. інтернет-конференція, присвячена 50-річчю заснування ХДУХТ, 3 жовтня 2017 р.: тези доп./ редкол.: О. І. Черевко та ін. Х.: ХДУЗТ, 2017. С. 57-59. 7. Мартинюк О. В., Озійчук В. О. Маркетинг в соціальних мережах. Актуальні проблеми теорії і практики менеджменту в контексті євроінтеграції : зб. тез VII Міжнародної науковопрактичної конференції, 16 травня 2019 року. Рівне : НУВГП. 8. Романишин С. Б., Греськів І. Р. Особливості маркетингової діяльності в соціальних мережах. Вісник Національного університету «Львівська політехніка». Менеджмент та підприємництво в Україні: етапи становлення і проблеми розвитку. 2015. № 819. С. 183-188. 9. Українці більше довіряють інтернету, ніж телевізору - пояснює експерт Internews. URL: 
Серія «Економічні науки»

Випуск 3(91) 2020 p.

http://ukr.radio/news.html? newsID=91174. (дата звернення: 16.09.2020). 10. Шиндировський І. М. Використання глобальної мережі Інтернет у бізнесі. Підприємництво і торгівля : зб. наук. праць. Львів : Видавництво ЛТЕУ, 2018. Вип. 22. C.132-135. 11.Як цифрові технології впливають на світ і Україну URL: https://sergioshtogryn.blogspot.com/2018/06/blog-post.html. (дата звернення: 16.09.2020). 12. Global Ecommerce Report. URL: https://www.ecommercefoundation.org/free-reports. (дата звернення: 16.09.2020). 13.12,6 млрд грн в год: большой анализ рынка онлайн-рекламы в Украине. URL: https://ain.ua/2020/02/27/126-mlrd-grn-v-god/ (дата звернення: 16.09.2020).

\section{REFERENCES:}

1. Hlobalna elektronna komertsiia: +2 trln dolariv dokhodu v 2019 rotsi. URL: https://blog.lengow.com/global-ecommerce-2019-report/ (data zvernennia: 16.09.2020). 2. Dovira ukraintsiv do ZMI za rik znyzylasia na $11 \%$. Ukrinform. URL: https://webcache.googleusercontent.com/search?q=cache:

46vqMJF3MBYJ:https://www.ukrinform.ua/rubricsociety/2803560-dovira-ukrainciv dozmi-za-rik-znizilasanahtml+\&cd=1\&hl=uk\&ct=clnk\&gl =ua. (data zvernennia: 16.09.2020). 3. Yevseitseva O. S., Merkulova D. D. Tarhetynh - tsilespriamovanyi vplyv na spozhyvacha. Ekonomika ta derzhava. 2019. № 3. S. 107-113. 4. Zvit «Tsyfrovi tekhnolohii 2020» (Digital 2020). URL: https://wearesocial.com/blog/2020/01/digital2020-3-8-billion-people-use-social-media\# (data zvernennia: 16.09.2020). 5. Kuklinova T.V. Internet-torhivlia yak zasib pidvyshchennia konkurentospromozhnosti pidpryiemstv v umovakh hlobalizatsii. Teoretychni, metodolohichni ta praktychni aspekty konkurentospromozhnosti pidpryiemstv : monohrafiia / za zah. red. O.H. Yankovoho. Odesa : Atlant, 2017. S. 183-191. 6. Malchyk M. V., Klimavichus Ya. I., Malchyk Ya. Ya. Marketynhovi internet-tekhnolohii v biznesi. Marketynhovi innovatsii $v$ osviti, turyzmi, hotelno-restorannii, kharchovii industrii ta torhivli : Mizhnarodna naukovo-prakt. internet-konferentsiia, prysviachena 50-richchiu zasnuvannia KhDUKhT, 3 zhovtnia 2017 r. : tezy dop./ redkol. : 0. I. Cherevko ta in. Kh. : KhDUZT, 2017. S. 57-59. 7. Martyniuk 0. V., Oziichuk V. 0. Marketynh v sotsialnykh merezhakh. Aktualni problemy teorii i praktyky menedzhmentu $v$ konteksti yevrointehratsii : zb. tez VII Mizhnarodnoi naukovo-praktychnoi konferentsii, 16 travnia 2019 roku. Rivne : NUVHP. 8. Romanyshyn S. B., Hreskiv I. R. Osoblyvosti marketynhovoi diialnosti $v$ sotsialnykh merezhakh. Visnyk Natsionalnoho universytetu «Lvivska politekhnika». Menedzhment ta pidpryiemnytstvo v Ukraini: etapy stanovlennia $i$ problemy rozvytku. 2015. № 819. S. 183-188. 9. Ukraintsi bilshe doviriaiut internetu, nizh televizoru - poiasniuie ekspert Internews. URL: http://ukr.radio/news.html? newsID=91174. (data zvernennia: 16.09.2020). 10. Shyndyrovskyi I. M. Vykorystannia hlobalnoi merezhi Internet u biznesi. Pidpryiemnytstvo i torhivlia : zb. nauk. prats. Lviv : Vydavnytstvo LTEU, 2018. Vyp. 22. S. 132-135. 11. Yak tsyfrovi tekhnolohii vplyvaiut na svit i Ukrainu URL: https://sergioshtogryn.blogspot.com/2018/06/blog-post.html. (data zvernennia: 16.09.2020). 12. Global Ecommerce Report. URL: https://www.ecommercefoundation.org/free-reports. (data zvernennia: 16.09.2020). 13. $12,6 \mathrm{mlrd}$ grn $v$ god: bolshoy analiz ryinka onlayn-reklamyi v Ukraine. URL: https://ain.ua/2020/02/27/126-mlrd-grn-v-god/ (data zvernennia: 16.09.2020). 
 \\ Malchyk M. V. [1; ORCID ID: 0000-0002-0917-191X], \\ Doctor of Economics, Professor, Head of the Department of Marketing, \\ Adasiuk I. P. [1; ORCID ID: 0000-0003-2575-2359], \\ Candidate of Economics (Ph.D.), Senior Lecturer of the Department of \\ Marketing \\ ${ }^{1}$ National University of Water and Environmental Engineering, Rivne \\ TARGET ADVERTISING AS A TOOL FOR PROMOTING BUSINESS PAGES IN THE SOCIAL NETWORKS}

In the article is explored popular sites, social networks and types of online media advertising. According to the analysis the most popular social networks are Facebook and Instagram. We explored the segments of media internetadvertising which often used in social media targeting.

The content of targeting was disclosed as the most effective advertising tool in the social networks.

Management and configuration of targeted advertising is provided in the advertising room «Ads Manager» of the social network Facebook. Instagram also has some ad settings that need improvement. Targeting on Facebook and Instagram begins of the analysis: sales market, competitors, target audience. So we have improved the targeting stages and tasks on Facebook and Instagram. There are three key stages: preparatory, targeting and final.

The targeting's indicators of the efficiency analysis have been considered. We've highlighted key metrics: frequency, impressions, budget, link conversions, conversion index and other. These indicators are available in the mode of adjusting the parameters of the advertising report and are automated in the advertising office. There are many indicators of analysis, but we have listed the most common in terms of practice using modern SMM agencies.

Targeted advertising on social networks is relevant for all activities, forms of ownership and business size. Therefore, we have sorted out the advantages and disadvantages of the targeting according to the main parameters, such as management, audience, budget, detailed targeting, performance analysis. Advertising on social networks is promising in the market of Internet advertising and remains a platform for finding and buying the necessary product.

Keywords: targeting advertising; advertising; internet-advertising; social network; advertising tools; website. 
Мальчик М. В. [1; ORCID ID: 0000-0002-0917-191X], д.э.н., профессор, заведующий кафедрой маркетинга,

Адасюк И. П. [1; ORCID ID: 0000-0003-2575-2359], к.э.н., ст. преподаватель кафедры маркетинга

${ }^{1}$ Национальный университет водного хозяйства и природопользования, г. Ровно

\section{ТАРГЕТИНГОВАЯ РЕКЛАМА КАК ИНСТРУМЕНТ ПРОДВИЖЕНИЯ БИЗНЕС-СТРАНИЦ В СОЦИАЛЬНЫХ СЕТЯХ}

В статье исследованы популярные сайты, социальные сети и виды медийной интернет-рекламы. Раскрыто содержание таргетинга как наиболее действенного рекламного инструмента у соцсетях. Усовершенствовано таргетинговые этапы и задания у сети «Фейсбук» и «Инстаграм». Рассмотрены показатели анализа результативности таргетинговой рекламы с раскрытием экономической сущности. Также упорядочено преимущества и недостатки таргетинга по основным параметрам его настройки.

Ключевые слова: таргетинговая реклама; реклама; интернет-реклама; социальная сеть, рекламные инструменты; веб-сайт. 